\title{
Microbiological quality of hamburgers sold in the streets of Cuiabá - MT, Brazil and vendor hygiene-awareness
}

\author{
Qualidade microbiológica de sanduíche comercializado nas ruas \\ de Cuiabá - MT, Brasil e a percepção dos manipuladores
}

\author{
Aída Couto Dinucci BEZERRA ${ }^{1 *}$, Regina Baptista dos REIS ${ }^{1}$, Deborah Helena Markowicz BASTOS
}

\begin{abstract}
This study evaluated the microbiological quality of hamburgers and the microbe community on the hands of vendors in Cuiabá, Mato Grosso, Brazil, in relation to vendors' awareness as to what constitute acceptable food-handling practices as part of a broad-spectrum research programme on street foods in Brazil. Sale of the hamburger known as the 'baguncinha' is common and widespread in urban Cuiabá, Mato Grosso, Brazil. Food inspectors encounter various difficulties in carrying out inspections. One hundred and five hamburgers samples were evaluated using conventional methods including tests for facultative aerobic and/or anaerobic mesophytic bacteria, coliform counts at $45^{\circ} \mathrm{C}$, the coagulase test for Staphylococcus, Gram-staining for the presence of Bacillus cereus, Clostridium sulphite reductase and Salmonella spp. The hamburgers were categorized as unsuitable for human consumption in $31.4 \%$ of samples, with those testing positive for coliforms and Staphylococcus at unacceptably high levels by Brazilian standards. High levels of microbiological contamination were detected on the hands of the food handlers and mesophytic bacterial counts reached $1.8 \times 10^{4} \mathrm{CFU} /$ hand. Interviews were carried out by means of questionnaires to evaluate levels of awareness as to acceptable food handling practices and it was found that $80,1 \%$ of vendors had never participated in any kind of training.

Keywords: food quality; food safety; education; evaluation.
\end{abstract}

\section{Resumo}

Este estudo avaliou a qualidade microbiológica de sanduíches e a microbiota nas mãos dos vendedores em Cuiabá - Mato Grosso, Brasil, relacionando com o conhecimento dos comerciantes sobre boas práticas de manipulação, como parte de um amplo programa de pesquisa sobre alimentos de rua no Brasil. O comércio de sanduíche denominado baguncinha é típico na região metropolitana de Cuiabá - Mato Grosso, Brasil. A vigilância sanitária tem problemas estruturais e financeiros para a fiscalização. Cento e cinco amostras de sanduíches foram avaliadas utilizando-se métodos convencionais de determinação de bactérias mesófilas aeróbias e/ou anaeróbias facultativas, contagem de coliformes a $45^{\circ} \mathrm{C}$, estafilococos coagulase positiva, Bacillus cereus, clostrídio sulfito-redutor e presença de Salmonella spp. Os sanduíches foram classificados como impróprios para o consumo em 31,4\% das amostras, com níveis de coliformes e de estafilococos coagulase positiva superiores aos padrões brasileiros. Altos níveis de contaminação microbiológica foram detectados nas mãos dos manipuladores do baguncinha e a contagem de bactérias mesófilas atingiu valores de $1,8 \times 10^{4} \mathrm{UFC} /$ mão. Foram realizadas entrevistas por meio de questionários para avaliar a percepção relacionada ao conhecimento sobre manipulação adequada de alimentos e 80,1\% dos vendedores nunca participaram de um treinamento.

Palavra-Chave: qualidade dos alimentos; segurança alimentar; educação; avaliação.

\section{Introduction}

Data from the bureau Family Budget Research estimate that $25.7 \%$ of the average of family outgoings is spent on eating out (Instituto Brasileiro de Geografia e Estatística, 2002). Contaminated food results in economic losses and poses a risk to human health (MUDGIL; AGGARWAL; GANGULI, 2003). Epidemiological data show that the prime cause of intestinal infections is eating from roadside food (MONSUPYE; HOLY, 2000). Department of Health food inspectors encounter logistical and financial difficulties in carrying out inspections of such places (DALLARI et al., 2000). The "Baguncinha" is a typical sandwich of the metropolitan region of the city of Cuiabá - MT, Brazil. It is an adaptation of the traditional version of the "X-Tudo" (bread, mayonnaise, hamburger, cheese, ham, Frankfurter sausage, egg, lettuce, and tomato) with fewer ingredients. The low price makes the sandwich popular among poor people, particularly adolescents. Even though some ingredients reach a temperature that is ideal to ensure the food is cooked thoroughly, crosscontamination during preparation has been traced back to the use of uncooked vegetables and unhygienic handling (FRANCO, 1996; SOTO et al., 1996; GERMANO M. I. S.; GERMANO P. M. L., 2003; REIJ; AANTREKKER, 2004). Hence, a study was carried out with Brazilian street vendors to verify whether any previous

Recebido para publicação em 19/8/2008

Aceito para publicação em 4/1/2009 (003787)

${ }^{1}$ Faculdade de Nutrição, Universidade Federal de Mato Grosso - UFMT, Rua Albuquerque Peixoto n.472, Jardim Independência, CEP 78030-220, Cuiabá, MT, Brasil,

E-mail: aidacdb@terra.com.br

2 Faculdade de Saúde Pública, Universidade de São Paulo - USP, São Paulo - SP, Brasil

${ }^{*}$ A quem a correspondência deve ser enviada 
food-preparation training have resulted in significant changes in incidences of contamination of food prepared by them (BEZERRA, 2007, 2008). Ineffective educational intervention has worried international health organizations which have encouraged the training of those food handlers (WORLD HEALTH ORGANIZATION, 2006). This study evaluated the microbiology of the "baguncinha" sandwich and the cleanliness of the sandwich makers' hands in Cuiabá in relation to their knowledge of Good Manufacture Practice (GMP) as part of a wider programme of hygienic and sanitary conditions involved in the preparation of street food in Brazil.

\section{Materials and methods}

Thirty five snack bars were evaluated in the period from March to July 2005. The sample comprised snack bars chosen at random from a selection situated in districts of urban Cuiabá that had been previously mapped out. The microorganisms researched included those that posed an indirect risk to the consumer's health, such as fecal coliforms; a direct risk, such as Salmonella and Staphylococcus (INTERNATIONAL COMMISSION ON MICROBIOLOGICAL SPECIFICATIONS FOR FOODS, 2006), and other indicators of contamination such as Clostridium sulphite reductase and Bacillus cereus (LANDGRAF, 1996). Three sandwiches with an average weight of $221 \mathrm{~g}$ were collected from each point of sale totalizing 105 samples analyzed. The samples were collected under aseptic conditions, wrapped in sterile plastic bags, sealed, appropriately labeled, and kept in ice boxes containing recycled ice (AMERICAN PUBLIC HEALTH ASSOCIATION, 2001).

The 35 vendors were told to wash both their right and left hands in saline solution contained in a sterile plastic bag, and this dirty water was then taken for bacteriological analysis (DESTRO, 1995; KARAM; MIGLIORANZA; OLIVEIRA, 1998)

Vendor awareness regarding to the appropriate hygiene for sandwich preparation was studied via responses to 13 questions (BEZERRA, 2007, 2008) included in the questionnaire (MINAYO, 2000; AZANZA; GATCHALIAN; ORTEGA, 2000; GERMANO, 2003).

The researchers' presence at the point of sale enabled systematic observation of sandwich handling practices and frequency of hand washing (BEZERRA, 2007, 2008).

Ethical aspects conformed to the Brazilian code of practice (Resolução CNS n.196/1996 (BRASIL, 1996).

\subsection{Sandwich microbiological analysis}

The microbiological analyses carried out included isolation and identification of pathogens, following standard procedures, to presumptively quantify Clostridium sulfite reducers, Bacillus cereus, Staphylococcus coagulase positive, the Most Probable Number (MPN) of coliforms at $45^{\circ} \mathrm{C}$, and the presence of Salmonella spp. (AMERICAN PUBLIC HEALTH ASSOCIATION, 2001; SILVA; JUNQUEIRA; SILVEIRA, 1997). Twenty-five grams of a sample sandwich were weighed, put in $225 \mathrm{~mL}$ of saline peptone solution (SPS) $0.1 \%$, and homogenized for the following procedures.

\section{Coliform counts at $45^{\circ} \mathrm{C}$}

The MPN of coliforms was determined using three series of dilutions $\left(10^{-1}\right.$ to $\left.10^{-3}\right)$. Using a sterile pipette, $1 \mathrm{~mL}$ of each dilution was transferred into a series of three tubes containing lauryl sulphate tryptose (LST) with Durham tubes and incubated at $36^{\circ} \mathrm{C}$ for 48 hours for the presumptive test. All tubes that had become turbid and in which gas had been produced were selected and transferred into tubes containing E. coli culture. They were then incubated in a bain-marie (or double-boiler) at $45^{\circ} \mathrm{C}$ for 48 hours. The tubes of $E$. coli medium that showed turbidity and gas production were quantified and the MPN of coliforms per gram was determined according to the MPN table for the three tubes (AMERICAN PUBLIC HEALTH ASSOCIATION, 2001; SILVA; JUNQUEIRA; SILVEIRA, 1997).

\section{Differentiation of Staphylococcus spp. using the coagulase test}

A $0.1 \mathrm{~mL}$ extract was drawn off from each of the series of dilutions $\left(10^{-2}\right.$ to $\left.10^{-4}\right)$ and poured into duplicate Petridishes containing Baird Parker Agar (BPA), spread with a Drigalsky handle, and incubated at $36^{\circ} \mathrm{C}$ for 48 hours. The dishes containing between 20 and 200 colonies were selected and expressed as Colony-Forming Units per gram of sandwich $\left(\right.$ CFU. $\left.{ }^{-1}\right)$. Typical and atypical colonies were tested using Gram staining, catalase, and coagulase tests (AMERICAN PUBLIC HEALTH ASSOCIATION, 2001; SILVA; JUNQUEIRA; SILVEIRA, 1997).

\section{Counts of clostridium sulphite reductase}

For the Clostridium counts, $0.1 \mathrm{~mL}$ of the dilutions $10^{-2}$ to $10^{-4}$ were spread on duplicate Petri-dishes containing tryptose sulphite cycloserine agar (TSC) using a Drigalsky handle. After drying completely, the Petri dishes were covered with a layer of TSC and incubated at $35^{\circ} \mathrm{C}$ for 24 hours in anaerobic conditions. After incubation, the Petri dishes containing between 20 and 200 of the black colonies that typify Clostridium cultures were selected. The result was expressed in Colony-Forming Units per gram of sandwich $\left(\mathrm{CFU} . \mathrm{g}^{-1}\right.$ ) (AMERICAN PUBLIC HEALTH ASSOCIATION, 2001; SILVA; JUNQUEIRA; SILVEIRA, 1997).

\section{Bacillus cereus counts}

An extract of $0.1 \mathrm{~mL}$ was taken from the $10^{-2}$ to $10^{-4}$ dilutions and spread on duplicate Petri dishes containing mannitol-egg yolk- polymyxin agar (MYP) using a Drigalsky handle. After the surface of the agar had dried completely, the Petri dishes were incubated at $30{ }^{\circ} \mathrm{C}$ for 24 hours. Following incubation, dishes containing from 10 to 100 typical B. cereus colonies were selected, and at least five were taken for confirmatory testing (APHA, 2001; SILVA; JUNQUEIRA; SILVEIRA, 1997). The result was expressed in Colony-Forming Units per gram of sandwich (CFU.g $\left.{ }^{-1}\right)$.

\section{Detection of Salmonella spp.}

Prior to enrichment, $25 \mathrm{~g}$ of the sample were homogenized in $225 \mathrm{~mL}$ of lactose nutrient broth (LNB) and incubated at $36{ }^{\circ} \mathrm{C}$ for 24 hours. Then, 1.0 and $0.1 \mathrm{~mL}$ of this suspension 
were then added to test tubes containing $10 \mathrm{~mL}$ of tetrathionate broth (TT) and Rappaport-Vassiliadis (RV) nutrient broth and incubated at 35 and $42{ }^{\circ} \mathrm{C}$ for 24 hours, respectively, in bainsmarie. Prior to that, a drop of each nutrient broth was spread on Petri dishes of Hoekten Enteric (HE) and Rambach (RAM) agar, previously incubated at $36^{\circ} \mathrm{C}$ for 24 hours. Presumptive colonies of Salmonella were placed into tubes containing Nutrient Agar (ANI) and incubated at $35^{\circ} \mathrm{C}$ for 24 hours. Typical Salmonella spp. colonies were subjected to biochemical tests in Triple Sugar Iron (TSI), Lysine Iron (LIA), and Simmons' citrate agar. The TSI and LIA agars were incubated at $35^{\circ} \mathrm{C}$ for 24 hours and that of Simmons' citrate at $35^{\circ} \mathrm{C}$ for 96 hours. Colonies manifesting biochemical behavior patterns similar to those of Salmonella were subjected to agglutination testing using polyvalent somatic anti-Salmonella serum (PROBAC) (AMERICAN PUBLIC HEALTH ASSOCIATION, 2001; SILVA; JUNQUEIRA; SILVEIRA, 1997).

\subsection{Bacteriological analysis of water vendors' hands were washed in (handwashing water)}

Microbiological analyses included standard counts in Petri dishes and quantification of Staphylococcus spp. that had been differentiated by testing positive in the coagulase test. For the standard counts in Petri dishes serial dilutions $\left(10^{0}\right.$ to $\left.10^{-2}\right)$ of hand washing water (water that vendors had washed both hands in) were made up with $0.1 \%$ saline peptone solution. Then, $0.1 \mathrm{~mL}$ extracts were spread on duplicate Petri dishes of Plate Count Agar (PCA) using a Drigalsky handle. The Petri dishes were incubated at $35^{\circ} \mathrm{C}$ for 48 hours. For the counts, Petri dishes with between 25 and 250 colonies were selected and the results were expressed in Colony-Forming Units per pair of Hands (CFU/H) (AMERICAN PUBLIC HEALTH ASSOCIATION, 2001; SILVA; JUNQUEIRA; SILVEIRA, 1997).

\subsection{Interpretation of results}

The interpretation of the microbiological results followed standards of the regulations in RDC n.12, which approves the technical regulation of food microbiological standards (ANVISA, 2001). Considering the lack of standards or official specifications concerning the interpretation of data on dirty water from hand washing, the quantification of pathogens from food-handlers' hands was established by adapting recommendations postulated by other authors (ALMEIDA et al. 1995; ANDRADE; SILVA; BRABES, 2003). The results for the levels of awareness regarding good practices in food preparation by sandwich vendors and the systematic observation of the practices employed when handling sandwiches were analyzed (AZANZA; GATCHALIAN; ORTEGA, 2000; BEZERRA, 2007; 2008) by means of the absolute and relative frequencies obtained using the programme SPSS 10.0 .

\section{Results}

Among the burger bars evaluated, eleven (31.4\%) were found lacking with respect to standards of hygiene, as shown in Table 1. They showed levels of fecal coliforms and Staphylococcus spp. above those allowed by specific Brazilian legislations (BRASIL, 2001).
The presence of Salmonella spp. was not detected in any of the sandwich samples analyzed. Bacillus cereus and Clostridium sulphite reductase were present but met hygiene standards allowed by the Brazilian law (BRASIL, 2001) (Table 1).

The hands of the sandwich makers' showed high levels of microbiological contamination in $80 \%$ of samples. The standard counts from the Petri dish cultures varied from $<10^{2}$ to $1.8 \times 10^{4} \mathrm{CFU} /$ hand and the Staphylococci counts varied from $1.6 \times 10^{2}$ to $4.4 \times 10^{4} \mathrm{CFU} /$ hand.

Questionnaire findings showed that among the vendors of 'baguncinha' sandwiches in Cuiabá, 27 (77.1\%) believed they possessed adequate knowledge of what constituted (GMP) good manufacture practice (Table 2). Only $19.9 \%$ of the vendors said they had acquired this knowledge through training. The rest mentioned other vendors, television, radio, newspapers, or magazines as sources of information about what constituted good standards of hygiene for the handling of foodstuffs.

According to the results of this study, $11.4 \%$ of sandwich samples of burger bars fell short of safe levels for fecal coliforms permmited by Brazilian laws (Table 3 ).

Only three $(8.7 \%)$ of the samples of burger bars were contaminated with Staphylococcus aureus; however the number of individuals was above the limit set by the RDC $n .12$ guidelines for sandwiches served hot (BRASIL, 2001), which is $10^{3} \mathrm{CFU} \cdot \mathrm{g}^{-1}$ (Table 4).

The hygiene level of contamination on the hands of the sandwich handlers researched was considered unsatisfactory in $80 \%$ of the handlers (Table 5).

Table 1. Microbiological profile of 'baguncinha' sandwiches compared with accepted Brazilian standards of hygiene.

\begin{tabular}{lcc}
\hline \multicolumn{1}{c}{$\begin{array}{c}\text { Microorganism } \\
\text { taxon }\end{array}$} & $\begin{array}{c}\text { Brazilian } \\
\text { standard }\end{array}$ & $\begin{array}{c}\text { "Baguncinha" } \\
\text { sandwich data }\end{array}$ \\
\hline Coliforms at $45^{\circ} \mathrm{C}\left(\mathrm{MPN} \cdot \mathrm{g}^{-1}\right)$ & $10^{2}$ & $<3$ a 887 \\
Staphylococcus spp. $\left(\mathrm{UFC} \cdot \mathrm{g}^{-1}\right)$ & $10^{3}$ & $10^{3} \mathrm{a} 1.7 \times 10^{6}$ \\
Bacillus cereus (UFC.g $\left.{ }^{-1}\right)$ & $10^{3}$ & $<10^{3}$ \\
Clostridium sulphite reductase (UFC.g $\left.{ }^{-1}\right)$ & $10^{3}$ & $<10^{3}$ \\
Salmonella spp./25 g & Absent & Absent \\
\hline
\end{tabular}

*BRASIL/ANVISA/RDC n. 12, 2001.

Table 2. Knowledge level about GMP perceived by sandwiches vendors. Cuiabá - MT (BRAZIL, 2005).

\begin{tabular}{llccc}
\hline & & Frequency & Valid (\%) & Cumulative(\%) \\
\hline Valid & Total & 35 & 32.9 & 62.9 \\
& Portially & 5 & 14.3 & 77.1 \\
& None & 8 & 22.9 & 100.0 \\
& Total & 35 & 100.0 & \\
\hline
\end{tabular}

Table 3. Safe level for coliforms at $45^{\circ} \mathrm{C}$ per burger bars in Cuiabá - MT, (BRAZIL, 2005 ${ }^{\mathrm{a}}$.

\begin{tabular}{llccc}
\hline & & Frequency & Valid (\%) & Cumulative (\%) \\
\hline Valid & No & 4 & 11.4 & 11.4 \\
& Yes & 31 & 88.6 & 100.0 \\
& Total & 35 & 100.0 & \\
\hline
\end{tabular}

aPermitted under Brazilian law. 
Table 4. Number of individuals of Staphilococcus aureus (CFU.g ${ }^{-1}$ ) of samples per burger bars in Cuiabá - MT (BRAZIL, 2005ª).

\begin{tabular}{lrccc}
\hline & & Frequency & Valid (\%) & Cumulative (\%) \\
\hline Valid & 100.00 & 32 & 91.4 & 91.4 \\
& 47000.00 & 1 & 2.9 & 94.3 \\
& 52000.00 & 1 & 2.9 & 97.1 \\
& 1700000.00 & 1 & 2.9 & 100.0 \\
& Total & 35 & 100.0 & \\
\hline
\end{tabular}

apermitted under Brazilian law.

Table 5. Level of contamination on the hands of the handlers researched in Cuiabá - MT (Brazil, 2005).

\begin{tabular}{llccc}
\hline & & Frequency & Valid (\%) & Cumulative (\%) \\
\hline Valid & Acceptable & 7 & 20.0 & 20.0 \\
& Unacceptable & 28 & 80.0 & 100.0 \\
& Total & 35 & 100.0 & \\
\hline
\end{tabular}

The maximum time for interviewing and collecting samples of food and hand washing water at the "baguncinha" hamburger bars was six hours per vendor, which corresponded to approximately $75 \%$ of the working day of the vendors researched. Although the majority of the food handlers (94.3\%) stated that they washed their hands frequently, this behavior was rarely $(11.4 \%)$ observed.

\section{Discussion}

Due to the informal nature of street food vending, little has been studied and published about this theme, thus making it relevant to engage in a detailed investigation from the standpoint of hygienic and sanitary quality (CARDOSO; SANTANA; GUIMARÃES, 2007).

Similar studies on the microbiological quality of sandwiches sold on the streets of São Paulo and Rio Grande do Sul showed high levels of contamination by fecal Coliforms (BROD, 2002; LOPES, 2005). These results probably reflect the dirtiness of the water used for hand washing by the sandwich makers, insufficient hand washing, insufficiently-heated food, and unsuitable conditions of ingredients storage. Therefore, the likelihood of contamination by fecal Coliforms in the sandwiches sold on Brazilian roadsides is similar to that which occurs in other countries in Latin America (GARIN et al., 2002).

The data found on the hands of the handlers researched in this study suggest that physical contact between the maker's hands and the sandwich could have been one of the possible causes of contamination by Staphylococcus aureus.

The high percentage of handlers with dirty hands was similar to that found by the analysis of hand and fingernail cleanliness of snack vendors in Presidente Prudente - SP (LOPES, 2005). Staphylococcus aureus is of great economic importance because apart from causing diseases, it can give rise to asymptomatic infections due to its ability to colonize different regions of an organism (OKURA et al., 2005).

The high rate of contamination of roadside foodstuff vendors' hands also stimulated a study in Jakarta, Indonesia.
Researchers took statements from vendors who claimed (50\%) that they always washed their hands before handling food. However, since these authors did not observe actual food handling at the snack bars concerned, they were unable to compare the stated practices (opinion) with observed practices (van KAMPEN et al.,1998).

The disparity between stated practices and those observed concerning the hand washing habits of the "baguncinha" sandwich vendors suggests that the high level of hand contamination might be explained by neglect of this essential step in good practice in the handling of foodstuffs. Similar results were obtained for studies of hot dog vendors in the city of São Paulo, whose authors concluded that the lack of hygiene was due to lack of knowledge (LUCCA; TORRES, 2002, 2006). Other authors have affirmed that the best way to reduce the risk of contamination is to train the people involved in food handling (OLIVEIRA et al., 2006).

It is opportune to emphasize that the likelihood of some consumers prefer badly processed hamburger associated to the precarious knowledge of vendors about GMP and the low microbiological profile of 'baguncinha' sandwiches suggests a potential risk of food poisoning.

However, due to the fact that the majority of 'baguncinha' sandwich makers believed they had adequate knowledge of good practices, it may be at least partially understood why education has not changed inappropriate handling practices (BEZERRA, 2007, 2008). This fact has important implications for the evaluation of the efficiency of educational intervention which seeks to change unsuitable foodstuff handling practices at the roadside.

The findings from this study point out a need of further investigations about educational programmes for street food handlers, mainly for the "baguncinha" vendors. Furthermore, educational interventions should extrapolate the field of information by including the consideration of values, customs, models, and social symbols that lead to specific forms of behavior and practices. The scientific vision should therefore be set aside and a significant advance be made in understanding the complexity of education and health.

\section{Acknowledgements}

The authors are grateful to M.G.Lima, F.G.Marini, and M.M.C.Souza for helping with the microbiological analyses and for the financial support provided by the foundations CAPES and FAPEMAT and.

\section{References}

ALMEIDA, R. C. C. A. et al. Avaliação e controle de qualidade microbiológica de mãos de manipuladores de alimentos. Revista de Saúde Pública, v. 29, n. 4, p. 290-294, 1995.

AMERICAN PUBLIC HEALTH ASSOCIATION - APHA. Compendium of methods for the microbiological examination of foods. Washington, DC: APHA, 2001.

ANDRADE, N. J.; SILVA, R. M. M.; BRABES, K. C. S. Avaliação das condições microbiológicas em unidades de alimentação e nutrição. Revista Ciência e Agrotecnologia, v. 27, n. 3, p. 590-596, 2003. 
AZANZA, M. P. V.; GATCHALIAN, C. F.; ORTEGA, M. P. Food safety knowledge and practices of street food vendors in a Philippines university campus. International Journal of Food Sciences and Nutrition, v. 51, p. 235-246, 2000.

BEZERRA, A. C. D. O sanduíche baguncinha nas ruas de Cuiabá MT: avaliação de intervenção educativa. 276 p. Tese (Doutorado) - Universidade de São Paulo, São Paulo, 2007.

BEZERRA, A. C. D. (Org.). Alimentos de rua no Brasil e saúde pública. São Paulo: Annablume, 2008. 224 p.

BRASIL. Ministério da Saúde. Conselho Nacional de Saúde. Aprova as diretrizes e normas regulamentadoras de pesquisas envolvendo seres humanos. Resolução nº196, 10 de outubro de 1996. Diário Oficial da União, Brasília, DF, 10 outubro 1996.

BRASIL. Ministério da Saúde. Agência Nacional de Vigilância Sanitária. Aprova o regulamento técnico sobre padrões microbiológicos para alimentos. Resolução RDC nº 12, 12 de janeiro de 2001. Diário Oficial da União, Brasília, DF, 12 janeiro 2001.

BRASIL. Ministério do Planejamento, Orçamento e Gestão. Instituto Brasileiro de Geografia e Estatística. Pesquisa de orçamento familiar. 2002. Disponível em: <http://ww.sidra.ibge.gov.br/bda/ orcfamn>. Acesso em: 3 nov. 2003.

BROD, F. C. A. et al. Avaliação das condições higiênico-sanitárias de lanches comercializados em vias públicas em cidades da região fronteira do Rio Grande do Sul. In: CONGRESSO BRASILEIRO DE CIÊNCIA E TECNOLOGIA DE ALIMENTOS, 18., 2002, Rio Grande do Sul. Anais... Rio Grande do Sul: Sociedade Brasileira de Ciência e Tecnologia de Alimentos, 2002. p. 3685-8.

CARDOSO, R. C. V.; SANTANA, G. R.; GUIMARÃES, T. F. D. O consumidor e a comida de rua em Salvador - BA: hábitos, conhecimentos e percepção de risco. Salvador: UFBa, 2007. p. 1-18. Relatório técnico.

DALLARI, S. G. et al. Vigilância sanitária de alimentos de consumo imediato no município de São Paulo: a importância da informação para o planejamento. Higiene Alimentar, v. 14, n. 76, p. 24-35, 2000.

DESTRO, M. T. Listeria monocytogenes em camarão (Penaeus brasiliensis): marcadores sorológicos e genéticos no monitoramento de sua disseminação em uma unidade processadora de pescado. Tese (Doutorado) - Universidade de São Paulo, São Paulo, 1995.

FRANCO, B. D. G. M. Critérios microbiológicos para avaliação da qualidade de alimentos. 1996. In: Microbiologia dos alimentos. FRANCO, B. D. G. M.; LANDGRAF, M. São Paulo: Atheneu, (1996). $182 \mathrm{p}$.

GARIN, B. et al. Multicenter study of street foods in 13 towns on four continents by the food and environmental hygiene study group of the international network of Pasteur and Associated Institutes. Journal of Food Protection, v. 65, n. 1, p. 146-152, 2002.

GERMANO, M. I. S. Metodologia de pesquisa aplicada ao diagnostico situacional. São Paulo: USP, 2003. 12 p.

GERMANO, P. M. L.; GERMANO, M. I. S. Higiene e vigilância sanitária de alimentos. 2 ed. São Paulo: Varela, 2003. 655 p.

INTERNATIONAL COMMISSION ON MICROBIOLOGICAL SPECIFICATIONS FOR FOODS. Use of epidemiologic data to measure the impact of food safety control programs. Food Control, v. 17, p. $825-837,2006$.

KARAM, L. B.; MIGLIORANZA, L. H. S.; OLIVEIRA, T. C. R. M. Avaliação da técnica de lavagem das mãos e luvas empregada por funcionários que manipulam produtos derivados de leite. In: CONGRESSO BRASILEIRO DE CIÊNCIA E TECNOLOGIA DE ALIMENTOS, 18., Rio de Janeiro. Anais... Rio de Janeiro: SBCTA, 1998.

LANDGRAF, M. Microrganismos indicadores. In: FRANCO, B. D. G. M.; LANDGRAF, M. 1996. Microbiologia dos alimentos. São Paulo: Atheneu, 1996.

LOPES, G. V. Alimentos de rua: quão perigosos eles são? Diário Popular. 2005. Disponível em: <http://www.diariopopular.com. br/22_11_05/artigo.html>. Acesso em: 22 nov. 2005.

LUCCA, A.; TORRES, E. A. F. S. Condições de higiene de "cachorroquente" comercializado em vias públicas. Revista de Saúde Pública, v. 36, n. 3, p. 350-352, 2002.

LUCCA, A.; TORRES, E. A. F. S. Street food: the hygiene conditions of hot-dogs in Sao Paulo, Brazil. Food Control, v. 17, n. 4, p. 312-316, 2006.

MINAYO, M. C. S. O desafio do conhecimento: pesquisa qualitativa em saúde. 7 ed. São Paulo: HUCITEC, 2000. p. 89- 248.

MONSUPYE, F. M. E.; HOLY, A. Microbiological hazard identification and exposure assessment of street food vending in Johannesburg, South Africa. International Journal of Food Microbiology, n. 61, p. 137-145, 2000.

MUDGIL, S.; AGGARWAL, D.; GANGULI, A. Microbiological analysis of street vended fresh squeezed carrot and kinnow-mandarin juices in Patiala City, Índia. International Journal Food Safety, v. 3, p. 1-3, 2003.

OKURA, M. H. et al. Contaminação em salgados (coxinhas) encontrados no centro da cidade de Uberaba, MG. Higiene Alimentar, v. 19, n. 132, p. 65-68, 2005.

OLIVEIRA, A. C. G. et al. Avaliação microbiológica de caldo de cana comercializado em ruas e condições de manuseio de manipuladores em São Carlos, São Paulo, Brasil. Caderno de Saúde Pública, v. 22, n. 5, p. 1111-1114, 2006.

REIJ, M. W.; AANTREKKER, E. D. D. Recontamination as a source of pathogens in processed foods. International Journal of Food Microbiology, v. 91, p. 1-11, 2004.

SILVA, N.; JUNQUEIRA, V. C. A.; SILVEIRA, N. F. A. Manual de métodos de análise microbiológica de alimentos. São Paulo: Livraria Varela, 1997.

SOTO, C. A. et al. Prevalência de Staphylococcus aureus en manipuladores de alimentos de una Universidad de la Región Metropolitana. Revista Médica de Chile, v. 124, p. 1142-1146, 1996.

van KAMPEN, J. et al. The microbiological quality of street foods in Jakarta as compared to home-prepared foods and foods from tourist hotels. International Journal of Food Sciences and Nutrition, v. 49 , p. $17-26,1998$.

WORLD HEALTH ORGANIZATION - WHO. Doenças de origem alimentar: enfoque para educação em saúde. Tradução de Domingos Tommasi. São Paulo: Roca, 2006. 208 p. 